\title{
Identification of insect-specific target genes for development of RNAi based control of the Eucalyptus gall pest Leptocybe invasa Fisher \& La Salle (Hymenoptera: Eulophidae)
}

\author{
Mathish Nambiar-Veetil, Manoharan Sangeetha, K S Sowmiya Rani, V Aravinthakumar, R K Selvakesavan, \\ Aiyar Balasubramanian, R Venkatachalam, Abraham Sanu Mary, John Prasanth Jacob, N Krishna Kumar
}

From IUFRO Tree Biotechnology Conference 2011: From Genomes to Integration and Delivery Arraial d'Ajuda, Bahia, Brazil. 26 June - 2 July 2011

\section{Background}

Eucalyptus is grown in around 3.9 Mha in India. Leptocybe invasa Fisher \& La Salle (Hymenoptera: Eulophidae) has emerged as a serious pest in Eucalyptus causing considerable loss of quality planting materials besides loss in productivity and quality of timber. Current strategies for its control include selected deployment of Eucalyptus clones tolerant to the pest resulting in several productive Eucalyptus genetic resources, not being considered for plantation programmes, as in the case of the widely planted Eucalyptus clone, ITC 10, and ITC 271. The securely ensconced grub within the gall for a period of around 4 months post oviposition makes it refractory to pesticide applications. This feature, however, makes plant- incorporated protectants, via RNAi approaches a potential strategy for engineering resistance [1-3]. However, application of RNAi technology requires determination of sequence information of insect-specific genes so that off-target effects in plants as well as human beings are avoided.

\section{Methods}

Grubs were collected from the galls of $E$. camaldulensis clones, APNP 1.1 and ITC 351, infested with $L$.invasa from the nursery of the Institute of Forest Genetics and Tree Breeding, Coimbatore, India. Genomic DNA was isolated from the grubs homogenized in liquid nitrogen using a modified CTAB protocol [4]. RNA was isolated from the grubs using Qiagen RNeasy plant mini kit,

\footnotetext{
* Correspondence: nvmathish@yahoo.com

Institute of Forest Genetics and Tree Breeding, Coimbatore, India
}

followed by cDNA synthesis using SmartScribe reverse transcriptase.

Grubs were also directly used for PCR amplification circumventing DNA isolation. Furthermore, to enable multiple PCR analysis, a single grub was collected into $50 \mu \mathrm{l}$ of sterile distilled water, vigorously vortexed for 2 min followed by brief denaturation at $95^{\circ} \mathrm{C}$ for $10 \mathrm{~min}$ and centrifugation at $10,000 \mathrm{rpm}$ for $10 \mathrm{~min}$. The supernatant was used for PCR analysis.

The PCR mix consisted either 100 ng genomic DNA or $100 \mathrm{ng}$ cDNA or a single grub or $2 \mu \mathrm{l}$ of supernatant from denatured grub, in $1 \mathrm{X}$ PCR buffer, $0.8 \mathrm{mM}$ dNTPs, $1 \mu \mathrm{M}$ of each primer, $2.5 \mathrm{U} P f u$ polymerase (Fermentas). The PCR conditions used were initial denaturation at $94^{\circ} \mathrm{C}$ for $5 \mathrm{~min}$, cycle denaturation at $94^{\circ} \mathrm{C}$ for $40 \mathrm{~s}$; annealing at $60^{\circ} \mathrm{C}$ for $40 \mathrm{~s}$; extension at $72^{\circ} \mathrm{C}$ for $2 \mathrm{~min}$ for 30 cycles, and a final extension of $72^{\circ} \mathrm{C}$ for 5 min. In case of grub PCR, initial denaturation was for $10 \mathrm{~min}$ at $95^{\circ} \mathrm{C}$. The PCR products were resolved on a $1.0 \%$ Agarose gel in $1 \mathrm{X}$ TAE. When multiple bands were obtained, the products were gel eluted and either directly sequenced or cloned into pGEMTeasy vector prior to sequencing. Sequencing was done using the ABI PRISM 3130 XL Genetic Analyzer using Big Dye Terminator version 3.1" Cycle sequencing kit through the commercial sequencing services available at Chromous Biotech India Pvt Ltd.

\section{Results and discussion}

Chitin synthase gene was partially amplified using the degenerate primer sets, CSF3 (5'-TGYGCGACHA TGTGGCACGARAC-3')/ CSR1 (5'-GTCCTCSCCYT 
GRTCGTAYTGCAC-3') and CSF1 (5'-YTGGAY GGMGACATMGAYTTC-3')/ CSR1 (5'- GTCCTCSC CYTGRTCGTAYTGCAC-3') [5] from genomic DNA and cDNA. CSF3/R1 primers yielded multiple bands of which the expected $1 \mathrm{~KB}$ size amplicon was sequenced. CSF1/R1 primers yielded an amplicon of $370 \mathrm{bp}$, which overlapped with the sequence from CSF3/R1. The sequence data obtained were aligned, annotated, and a sequence of 624 bp was submitted to NCBI (Accession number: JF772551/to be published). The sequence comprising 2 exons and 2 introns, corresponded to 138 amino acids on conceptual translation. BLAST analysis of the nucleotide sequence showed $85 \%$ homology to Nasonia vitripennis chitin synthase 1 and $76 \%$ to Apis mellifera krotzkopf verkehrt (chitin synthase1) sequences. Furthermore, a rapid method of PCR amplification directly from grubs was developed. The amplicons generated using the primers CSF1/CSR1 yielded the same sequence, indicating its utility for rapid PCR screening of $L$. invasa grubs. In order to identify housekeeping genes for use as reference genes during quantitative PCR analysis, Elongation factor-1 alpha (EF1 alpha) was partially amplified using primers EF1-F (5'-GGTATCGACAAA CGT ACCATCG-3') /EF1-R (5'- AATCGAGCACAGG TGTGTAACC-3') and the sequence data of $534 \mathrm{bp}$ was submitted to NCBI (Accession number: JF772552/to be published). Blast analysis of this sequence showed $91 \%$ similarity to $N$. vitripennis EF-1 alpha.

\section{Conclusion}

Basic techniques like nucleic acid isolation and PCR amplification were adapted for this less studied insect pest. A rapid method for PCR amplification directly from the insect grub was developed for use in L. invasa. Our efforts have unraveled the partial gene sequence of L. invasa chitin synthase, a processive enzyme involved in chitin biosynthesis during different stages of insect development. The sequence of chitin synthase and EF-1 alpha represent the first genome sequence information for L. invasa. Chitin synthase offers a potential target for RNAi based pest control owing to its crucial role in

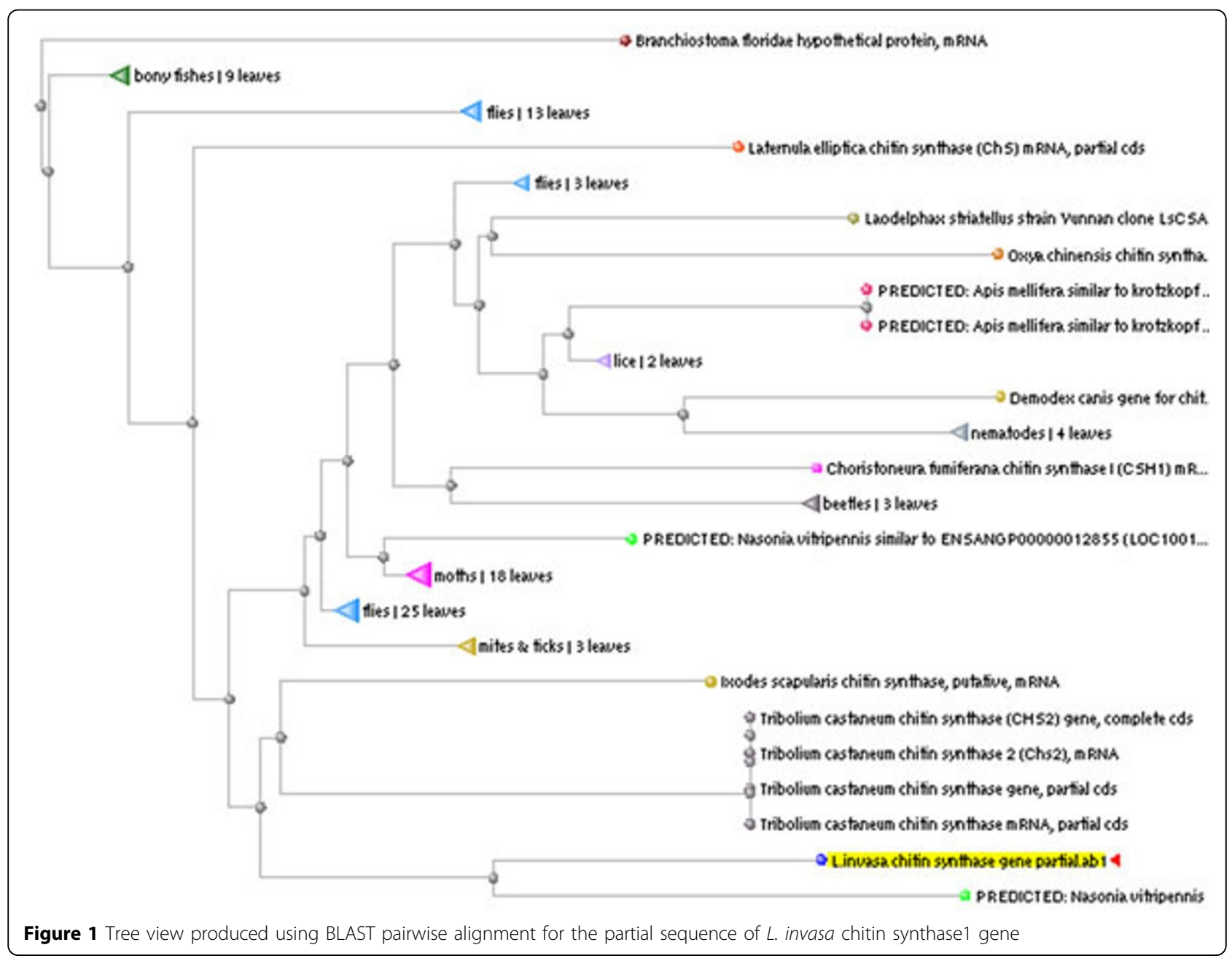


growth and development of insect. Following full length sequence determination of $L$. invasa chitin synthase gene, RNAi target regions will be chosen for development of RNAi constructs. EF-1 alpha will be used as the reference gene in RT-PCR studies to quantitate the effect of RNAi on the transcript levels of the target gene. The effect of Eucalyptus-expressed dsRNA molecules cognate for chitin synthase, will be evaluated on the growth and development of $L$. invasa. Towards this end, protocols have been optimized for generation of transgenic Eucalyptus[6].

Published: 13 September 2011

\section{References}

1. Baum JA, Bogaert T, Clinton W, Heck GR, Feldmann P, llagan O, Johnson S, Plaetinck G, Munyikwa T, Pleau M, Vaughn T, Roberts J: Control of coleopteran insect pests through RNA interference. Nat Biotechnol 2007, 25(11):1322-6.

2. Mao YB, Cai WJ, Wang JW, Hong GJ, Tao XY, Wang $L$, Huang YP, Chen XY: Silencing a cotton bollworm P450 monooxygenase gene by plantmediated RNAi impairs larval tolerance of gossypol. Nat Biotechnol 2007, 25(11):1307-13.

3. Mao YB, Tao XY, Xue XY, Wang LJ, Chen XY: Cotton plants expressing CYP6AE14 double-stranded RNA show enhanced resistance to bollworms. Transgenic Res 2010, DOl10.1007/s11248-010-9450-1.

4. Chen H, Rangasamy M, Tan SY, Wang H, Siegfried BD: Evaluation of Five Methods for Total DNA Extraction from Western Corn Rootworm Beetles. PLoS one 2010, 5(8):e11963.

5. Kumar N.S, Tang B, Chen X, Tian H, Zhang W: Molecular cloning, expression pattern and comparative analysis of chitin synthase gene $B$ in Spodoptera exigua. Comp Biochem Physiol B 2008, 149:447-453.

6. Mathish NV, Lalitha S, Sudha N, Brindha D, Prashant K, Balasubramanian A, Sumathi R, Karthikeyan C, Sharadha N, Shanthi A, Sivakumar V, Yasodha R, Suryaprakash M, Franche C, Gherbi H, Swistoonoff S, Florence A, Hocher V, Bogusz D, Blumwald E, Gurumurthi K: Optimization of genetic transformation methods in Eucalyptus: towards understanding and enhancing salt tolerance. National Conference on Frontiers in Plant Molecular Biology Bharathidasan University, Tiruchirappalli; 2010.

doi:10.1186/1753-6561-5-S7-P98

Cite this article as: Nambiar-Veetil et al:: Identification of insect-specific target genes for development of RNAi based control of the Eucalyptus gall pest Leptocybe invasa Fisher \& La Salle (Hymenoptera: Eulophidae). BMC Proceedings 2011 5(Suppl 7):P98.

\section{Submit your next manuscript to BioMed Central and take full advantage of:}

- Convenient online submission

- Thorough peer review

- No space constraints or color figure charges

- Immediate publication on acceptance

- Inclusion in PubMed, CAS, Scopus and Google Scholar

- Research which is freely available for redistribution

Submit your manuscript at www.biomedcentral.com/submit
C Biomed Central 